\title{
Pablo Fagundes and the Instrumental Music of Brasília
}

\section{Bryan McCann}

\author{
—“'m preparing the ground for some dissonance."1
}

Pablo Fagundes has been playing "Cai Cai, Balão" on the chromatic harmonica while scrambling along a rocky riverbed in the Chapada dos Guimarães in central Goiás. "Cai Cai, Balão" is a carnival march from the 1930s that for decades has been a popular children's song. But Fagundes has been playing the simple melody with the slide on his chromatic harp only half-engaged, so he simultaneously blows $\mathrm{C}$ and $\mathrm{C \#}$. He delivers his line about dissonance in a nasal, duck-like voice; in case we needed further evidence that he is only joking-or half-joking. But the other members of the party-fellow musicians and friends-are not necessarily as agile on the rocks as Fagundes, and they mostly tune him out. That's just Pablo.

Later that night, at a restaurant in the bohemian tourist village of São Jorge, in the heart of the Chapada, Fagundes and colleagues play what is more typical fare for them-the music of Edu Lobo, Hermeto Pascoal, César Camargo Mariano, and Sivuca, as well as their own compositions, leavened with some classic sambas from Cartola, Paulinho da Viola, and Dorival Caymmi. The musicians-Fagundes on harmonica, George Lacerda on percussion and vocals, Bruno Berê and Fabiano Nascimento on guitars_dig deep into the harmonic possibilities of each tune, stretching out their solos and pushing each other further. But occasionally, between tunes, Fagundes slips in a few bars of "Cai Cai Balão" in semi-tones. By the end of the long night, it is one of the running gags that seems, as much as their adventurous and demanding approach to Brazilian instrumental music, to sustain the friends.

Fagundes, Lacerda, and Berê are from Brasília and are fixtures of that city's thriving instrumental music scene. Nascimento is from Los Angeles, only in town briefly, but is an honorary brasiliense or resident of Brasília, wellversed in the city's emerging musical lexicon.

Brasília is best known as a rock town, home to Legião Urbana, Capital Inicial, and other great BRock (Brazilian Rock) bands of the 1980s. Throughout the city's rock boom, however, roqueiros shared space with-and in many cases converted into-devotees of choro, a Brazilian instrumental genre consolidated in the late nineteenth century and repeatedly updated since then, characterized by rigorous form, rich counterpoint, and major to minor modulation. The modernist capital has also always nurtured a traditional Northeastern city in its interstices and periphery-most of the workers who built Brasília were candangos, or migrant workers from the Northeastern sertão, or drought-stricken interior. Forró, the accordion and triangle-driven dance music of the sertão, has always thrived in the candango city.

The current generation of brasiliense instrumentalists ties together these traditions, playing choro-derived compositions with a rock attitude, often set to the rhythms of forró. There are two guiding luminaries for this music, Hermeto Pascoal and Hamilton de Holanda. Hermeto is not brasiliense, but his knotty, unpredictable compositionsmany of which start out as straightforward choro or baião (the root rhythm of forró), only to wander into stranger harmonic pastures_-provide the foundational inspiration for many of the brasilienses. Hermeto is known among Brazilian musicians as o bruxo-the wizard-and Brasília's instrumentalists utter that honorific with a particular awe. Mandolin virtuoso Hamilton de Holanda is a local who cut his teeth in Brasília's rodas de choro and started cracking open their conventions with his fiery playing as a young teenager. By his early twenties, he and a few fellow travelers-including his brother Fernando and guitarist Daniel Santiago-had begun to fashion a new kind of Brazilian instrumental music, deeply rooted in choro, but drawing on the extended harmonies Hamilton learned in his composition classes at the Universidade Nacional de Brasília, and featuring the rapacious solos of a tight jam band. Hamilton and Santiago relocated to Rio de Janeiro in the first years of the new century, but Hamilton's tidal influence has buoyed a generation of brasiliense musicians.

For Fagundes, a third figure is equally important, fellow harmonicist Gabriel Grossi, another brasiliense who relocated to Rio. Grossi is a founding member of Hamilton's quintet, along with Santiago. Their Brasilianos CDs, volumes 1 (2005) and 2 (2010), have an iconic status in the capital's instrumental circles. You could play three seconds from the middle of any track on Brasilianos and any brasiliense musician could identify it and scat the rest of the passage.

Fagundes wrote one of his best-known compositions, "Maracatu pra tu," in Grossi's honor. The tune builds a basic maracatu rhythm - another Northeastern genre, this one characterized by a mesmerizing beat that seems to turn itself inside out over two measures_into an ominous harmonica stomp. On Fagundes's 2009 Foles CD, "Maracatu pra tu" is arranged for harmonica, acoustic bass, and violin. Ted Falcon, another Los Angeles musician (in this case one who has fully relocated to Brasília), coaxes the twangy tonalities of the rabeca-the solid-bodied nordestino 
fiddle-from his violin, blending these with the chops that come from years of classical and jazz study. On this tune, Fagundes plays primarily in octaves, using a demanding technique that requires the musician to blow out of both corners of his mouth at once, while blocking three holes on the harmonica with his tongue. Playing in octaves makes the instrument sound more like a sanfona, or simple accordion, giving Falcon and Fagundes the sound of a nordestino band that has wandered the sertão—-the harsh badlands of the Northeastern interior-so long it has begun to hallucinate to a Hermeto soundtrack.

Halfway through the tune, they play a vertiginous cadenza in unison, leaping across dramatic intervals without losing the rhythmic pull of the maracatu. This passage was originally a Fagundes improvisation and then became part of the composition, although both musicians play it by ear and it has never been written down. This is typical of the brasiliense scene and part of what distinguishes it from approaches more typical of jazz on the one hand and choro on the other. The brasilienses frequently turn improvisations into arrangements, repeating and refining them over time, playing them in unison or in harmony. In jazz, a similar process might yield a new "head"-a new melody to serve as the basis for further improvisation. In the brasiliense instrumental scene, these passages tend to get packed into existing compositions, adding a layered density to arrangements passed from one musician to another, primarily by ear.

Like much of brasiliense instrumental music, "Maracatu pra tu" is a statement: this is how far you can push maracatu and still make it groove. This composition also displays Fagundes's chops and highlights his unique approach to his instrument.

Returning from the Chapada in Fagundes's dusty Chevrolet at $140 \mathrm{~km} / \mathrm{h}$, the musicians listen to Grossi's $2006 \mathrm{CD}$ Horizonte. Grossi's compositions test his bandmates with sudden key changes and odd time signatures (have you ever tried to improvise in 7/4?), and their victory is to turn these challenging compositions into inviting samba-jazz. After listening to one particularly intrepid Grossi improvisation, Fagundes remarks-as much to himself as to anyone else in the car-"Esse cara é muito escroto": That dude is really perverse. ${ }^{2}$ The way he says it makes it clear that escroto is the highest compliment one musician can pay another.

Even in Rio or São Paulo_or New York, for that matter-it is difficult to make a living playing music that makes these kinds of demands on its audience. In Brasília, where there are many strong musicians and relatively few venues, it is impossible. Because their music remains deeply rooted in popular dance rhythms and includes liberal doses of rock power, the brasiliense musicians frequently get their fans up and dancing. But these are fans that are not intimidated by a five-minute mandolin solo over an $\mathrm{Em}^{9}$ to $\mathrm{F}^{6 / 9}$ vamp, played at earsplitting volume. It is not an experience for everybody.

Every weekday, consequently, Fagundes heads to his day-job, teaching harmonica at the choro school in Brasília's legendary Clube do Choro, the anchor for the city's choro scene since the 1970s. His fellow faculty include many of the city's top instrumentalists-cavaco player Marcio Marinho, guitarists Rafael dos Anjos and Henrique Alves, viola caipira player Cacái Nunes, Rafael Black on pandeiro, and Falcon on violin, to name a few. ${ }^{3}$ Most of these teachers are either in their early 30s, like Fagundes, or younger (cavaco prodigy Marinho is in his early 20s), but they all feel the pressure of a younger generation-their own students-hot on their heels.

Fagundes runs all his students through a series of exercises: F major scale ascending, F major scale descending, ascending three notes at a time then descending, now arpeggios, now chromatic lines. The advanced students reel these passages off with practiced dexterity.

After attending classes, it is not difficult to spot these building blocks in Fagundes's own solos. A Gmaj ${ }^{7}$ arpeggio $^{+}$ from $\mathrm{F}^{\#}$ to $\mathrm{F}^{\#}$ turns into a descending chromatic line, punctuated by rhythmic blasts in octaves. But just when you feel you are getting a handle on where all this noise is coming from, Fagundes will pivot off an odd Hermeto-inspired chord and take the solo in a different direction. It is then clear what he has been doing with all those scale exercises: preparing the ground for a little dissonance. ${ }^{4}$

\section{Notes}

1 In the original Portuguese: "Estou preparando o terreno para um pouco de dissonância." 
2 Escroto is an adjective that literally means "scrotal." Like most popular slang, its significance in conversation depends largely on context, and in Brasilia the intensity with which it suggests repugnance in one context is matched by its suggestion of an almost unfair level of devastating talent in another, such as in the present example.

3 The cavaco is a small instrument of the guitar family, closely related to the ukulele, used prominently in traditional choro. The viola caipira is a ten-string guitar with five pairs of strings tuned in octaves, typical of Brazilian rural music. The pandeiro is known internationally as the tambourine, but when played in the Brazilian style it takes on the expressive range of a drumset. It bears noting that seven-string guitar is at least as prominent as six-string in choro, and is consequently one of the key instruments used in the brasiliense scene.

${ }^{4}$ A mini-documentary on Fagundes's work can be seen here: http://www.youtube.com/watch?v=vxJEZUYoVK4 